\title{
On methods of sustainable architectural design of bio-positive buildings in the low-rise residential development structure
}

\author{
Anna Zhogoleva ${ }^{*}, 1$, and Alexandra Teryagova ${ }^{1}$ \\ ${ }^{1}$ Samara State Technical University, Institute of Architecture and Civil Engineering, \\ Molodogvardeyskaya St, 194, Samara, 443001, Russia
}

\begin{abstract}
The purpose of the author's research is to determine the actual content of sustainable architectural design for suburban residential development. In accordance with the methodology of area sustainable development the traditional architectural design according to the rules and regulations is completed with additional approaches and methods. As a result, methods of bio-positive design of buildings have been studied and defined, including: the principle of planning transformations, the use of environmentally friendly, local building materials and design concepts, energy-efficient architectural design, the use of alternative energy in building operation, the design of the energy intake and accumulationsystems, the architectural and landscape design that ensures stable functioning of autonomous, sustainable biosystems on the site, nonwaste functioning of architectural objects, introduction of waste disposal systems in the project.
\end{abstract}

\section{Introduction}

Design and construction of energy efficient buildings is important and essential part of the contemporary architectural practice - design goals are achieved by experts - designers, engineers, architects. National and international systems of standardization and regulation of buildings energy efficiency are developed, moreover great attention is paid to climaticengineering and constructive indicators [1]. An important task of a modern architect is to actualize architectural and planning peculiarities of bio-positive buildings; to formulate methodology of energy efficient design bearing in mind these peculiarities.

Design and construction of energy efficient housing in Russia is still an actual issue of numerous discussions. This issue includes many aspects: climatic, economic, architectural and constructional and functional-spatial. Designing residential apartment buildings, which requires passing passing through the State expert review, is often based on traditional planning, design and engineering solutions as innovation enter this sphere design in Russia rather slowly. Low-rise individual housing construction actively relies on the use of more efficient, low-cost design solutions that enable autonomous use, independent of energy general supply systems. This paper gives basis to main principles of "sustainable

\footnotetext{
*Corresponding author: annazhogoleva@yandex.ru
} 
architectural design" for low-rise residential buildings, acceptable and typical for modern Russia.

\section{Materials and Methods}

This research is of general-theoretical nature and its main task is to put forward the most effective methodology for sustainable design of low-rise residential buildings in the climatic conditions of Russia, including the Volga region. These territories are characterized by continental climate temperate of middle latitudes with a large annual amplitude of temperature of air (hot summers and cold winters). The key aspect for designing in Russia is its climate as it makes impossible to develop a common strategy for sustainable design methodology. There are seven climatic zones in the country, so it is logical that there should be a separate study for each of them to offer the most rational decision.

The content of the sustainable architectural design of suburban residential development is expanded: traditional architectural design according to the rules and regulations is completed with additional approaches and methods of architectural design of bio-positive buildings. Among them are:

1.The method of planning transformations (integration of dwelling into natural, social and industrial environment, gradual spatial development, achieving an optimum balance of closed, open and semi-open spaces).

2. Reference to regional and national traditions of residential house construction.

3. The use of environmentally friendly, local building materials and design concepts.

4.Energy efficient architectural design. The use of alternative types of energy during buildings and structures operation, design of systems for energy intake and accumulation [2].

\section{Results}

\subsection{The method of planning transformations}

Important part of the "sustainable architectural design" methodology is the method of planning transformations, which is implemented with the help of the following techniques:

a) gradual spatial development of a residential building.

For "growing" suburban houses the following architectural techniques are recommended: combination of heated space with different "additional" planning elements: spacious porches, galleries, glazed verandas, sheds or a winter garden. The gradual vertical building extension is also possible: arrangement and insulation of open terraces on the second floor to create additional bedrooms. Insulation and renovation of the attic space for using them as rooms can be made if there is free space for staircase installation; the attic floor, designed as interfloor, in case the increased loads from people and furniture have been calculated, and also the attic space free from struts, props and other truss elements. Frequent use of cantilevers and extension spaces in the design allows increasing the house cubage depending on the needs of its owners.

In modern architectural practice the low-rise housing systems similar to the "modular construction set" are used. It allows to begin planning and building of a house with a small area, and then to expand the building without affecting the already built rooms. This approach to "growing architecture" is based on the unification of architectural and construction systems with their possible optional use, the modularity of the cubage and structures, ready architectural solutions at all stages of growth. 
The modular elements of the house usually have the same total dimensions in the plan. In his project of the growing home "Mera" (Measure) architect D. Dorokhin presents residential module as a self-supporting timber frame, filled with insulation and clad with wood or plastered with clay[3]. The frame consists of a single-type element placed at a certain interval along the entire length (Fig.1,B). It may be made of laminated wood, wooden trusses, square-edged boards. The modules are mounted through the end bearing elements by means of dismantling and replacing the end wall, the structure of which is selfsupporting with a uniform frame. It enables the replacement of windows for doors and the extension of openings (Fig.1,б). As a result, due to different modules blocking, the smallest dwelling can be transformed as and when necessary into a large full-scale house for the whole family (Fig.1,a).
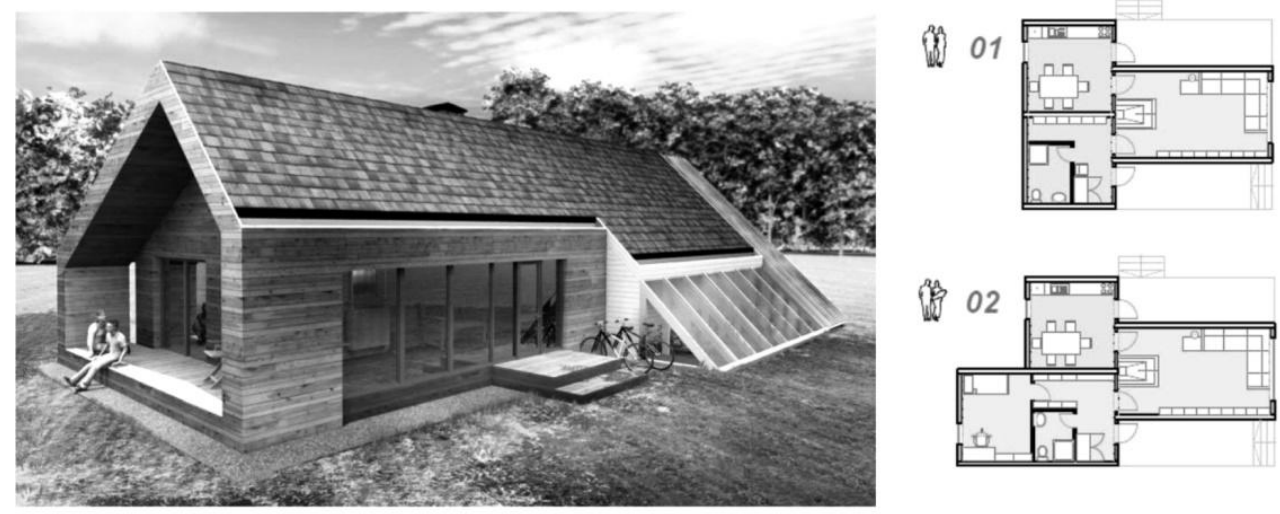

a)
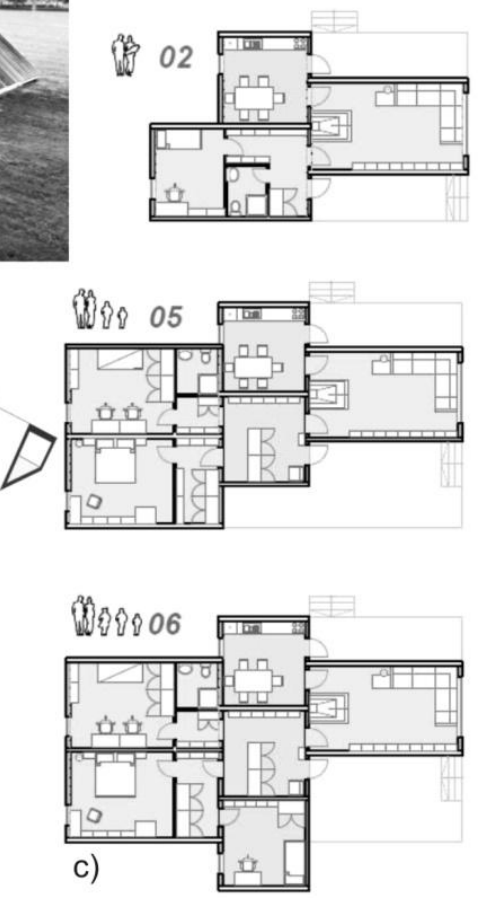

Fig.1. The project of the growing house "Mera," by architect D. Dorokhin

b) achieving an optimum balance of closed, open and semi-open spaces of a house. A suburban residential house has in its structure closed spaces (warm, heated part of the house), semi-open - verandas, galleries, balconies and fully open - terraces, platforms, pergolas, porches without canopies or other shelters. The degree of space expansion into the environment characterizes one or another mode of the house operation and is conditioned by the need to protect interior spaces of a living cell from the harmful impact of the extra sun, wind, cold, snow-wreath, dust storms. There are four operating modes: isolated, closed, adjustable and open. 
"Querkraft Architects" Architectural Bureau designed the project of a bio-positive residential building in the suburbs of Vienna, the capital of Austria, where they offered to place summer open spaces not only on the ground floor but also on the second floor and in the accessible roof area.

In temperate climate it is possible to use semi-open (adjustable) spaces up to 4 months of the year, that is why the summer premises can be better developed, but their total area should be within the specification limits: in country houses the floor-space of a veranda should be limited up to $20 \%$ of the apartment space. Under conditions of cloudy weather, it is recommended to use bay windows and "green rooms". In winter period the "green room" is either excluded from the total space of the house, or it is possible to isolate it from cold by transformable devices. In summer period the open "green room" with outdoor areas next to the house will constitute a single open space. Summer premises can be included in the spatial system of collective zone with the help of transformable outer fences. The residential complex MGR in Vienna by Architectural Bureau "Querkraft Architects" has not only accessible roof area of the residential building, but also the detailed composition of the semi-open summer premises as part of its apartments (Fig.2).
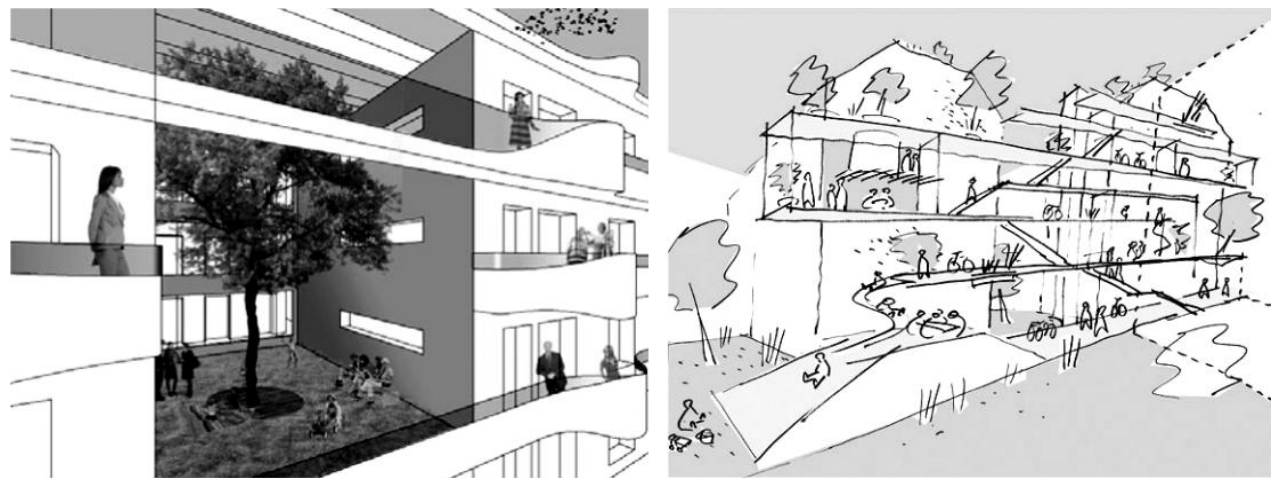

Fig.2. Residential complex MGR, Vienna, Austria, Architectural Bureau "Querkraft Architects".

\subsection{Reference to regional and national traditions of residential house construction.}

Reference to regional and national traditions of residential house construction is important part of sustainable designmethods. Regional, natural-climatic and national-economic conditions historically predetermined the specific character of architectural management of housing development. That specific character should be identified and taken as a basis of sustainable design methodology [4]. Among these conditions are:

a) spatial organization of mansion development. Subsidiary plots management requires constant (throughout the whole year) movement of residents from a house to household outbuildings. This communication can be performed via an open courtyard or unheated/heated architectural spaces, galleries, and semi-open passages, which are adjacent to outbuildings. There are:

- pavilion type of typical South Russian mansion development - open structure of the estate;

- blocked type of typical Central Russian mansion development - partially-closed, semi-open structure of the estate; 
- compact type of development with active vertical zoning of a typical North Russian mansion into residential and utility premises (basement, shed) - closed structure of the estate.

b) specific features of spatial organization of common areas (for eating, housework, cooking, receiving guests), depending on climatic conditions[5]:

- organization of a large in terms of area and cubic capacity space for universal use in the heated zone of a dwelling (a hut) under conditions of Northern regions (the yard of the "purse" type or "plank" type).

- organization of a space for universal use in the unheated zone of dwelling blocks - a chamber (for eating, housework, receiving guests and organizing feasts) under the climate conditions of the country central part.

- organization of a space for universal use in summer premises located in the courtyard, that has the core hearth - furnace and summer kitchen in the Southern regions.

c) energy efficiency of planning solutions of a residential house in the context of climatic conditions of householding:

- protection from the wind in the central part of the country: construction of houses in a staggered order (decrease of shadingarea, wind protection), reduction of the windward facades surface, reduction of their "punching".

- ventilation and protection against overheating in hot climate: developed eaves of the roof, large covered verandas, roundabout galleries, premises of pavilion type, that improve ventilation in the area and provide cross-ventilation of buildings. In dry and hot climates the protection from solar radiation and dust storms is provided with the help of atrium layout of an individual house - a landscaped and irrigated inner courtyard, surrounded with open galleries, so that all the rooms open up into this courtyard at different levels for air circulation. The side of this square courtyard is equal to the height of the house.

- protection against heat loss in cold climate: protection of light openings from heat loss with the help of internal and external blinds, especially for the windward and North facades, compactness of space-planning solution of the house "thermal volume", reduction of the walls cooled surfaces, the entrance into the house through a porch, canopy and vestibule, orientation of cold, utility rooms of the house, and a sheltered courtyard to the North, vertical functional development of a residential house.

\subsection{Use of environmentally friendly, local building materials and design concepts}

This is important part of sustainable architectural design. It is recommended to use natural materials (preferable those which are widely-used and traditional for the climate - brick, timber, natural stone, tile, glass, etc.). Also it is recommended to use materials that can be recycled or reused during reconstruction work with minimal losses after performing initial functions: natural stone, timber, glass, aluminum. It is not recommended to use synthetic finishing materials that emit harmful substances during production and operation; the use of reinforced concrete and steel is limited.

Today, when it comes to the construction of more economical and mass low rise housing, the attention of specialists is drawn to the construction of buildings from prefabricated parts and structures combined with local, eco-friendly building materials, including construction of individual houses from precast frame systems. In well-known Canadian architect Avi Friedman's opinion expressed in the middle of last decade, "in ten years, the role and functions of homebuilders will significantly change. The houses will be built on a mass scale from standard panel or modular components, designed with the help of computers using technology that resembles auto assembly line. Companies will mainly 
sell in the market "packages", standard units, assembled at the factory in accordance with the design approved by customers and transported almost ready."

A new generation of architectural and building systems of industrial house construction involves the use of frame structures based on bent cold metal profile, wooden structures processed at the factory, monolithic and precast-monolithic wall structures with insulation and cladding, wall structures with lost formwork made of expanded polystyrene or aerolite. Several types of architectural and structural systemsare used: framed, board-framed, panelframed. The building frame can be made of both solid (metal, timber, reinforced concrete) structures and light weight (metal, timber) ones.

There are examples of constructing low-rise houses with a steel supporting frame. Powerful supporting steel frame made of I-beam or channels can support reinforced concrete floors and masonry from aerated concrete or brick, although it is possible to make the walls fully glazed. Frames of laminated veneer lumber are more commonly used in housing construction. Designing of houses with a timber frame from laminated veneer lumber allows obtaining large flights, panoramic façade glazing, internal spaces of the building free from walls. Company "Visillatalot" (Finland), one of the leading companies on the market of manufacturing and constructing wooden houses from laminated veneer lumber, also offers frame design concepts.

Light steel and wooden structures of frame houses are more economical. The time required for construction of a building with a light steel frame (LSTS-Light steel thinwalled structures) is 2-3 times less than of a similar concrete one. The LSTS construction method in load-bearing structures presupposes the usage of thin-walled profiles with through cutting slots.

Some projects offer architectural and construction systems of industrial house-building on the basis of a simple timber frame [6]. In this case little weight of light timber structures allows designing light, cost-effective foundation. Industrial production makes it possible to manufacture houses in heated shops under the supervision of experts with a high degree of accuracy of manufactured parts - the tolerance is $1 \mathrm{~mm}$. As a result it takes only 4 days to assemble the house with perfect accuracy from prefab units on the site.

An important element of the architectural and structural systems of industrial housebuilding are heat-insulation materials. Among the most common non-combustible insulation materials are fibered glass, basalt continuous fiber, expanded clay (Fig.3,a). The fact that these materials are non-combustible means that in description of their characteristics in the column "fire" there is the symbol NC. In recent years, the construction industry has offered and distributed the most advanced innovative specialized thermal insulation materials and production methods that give great opportunities to optimize the basic indexes of construction energy efficiency.

Recently the combined type of heat-insulation design - the so-called ICF (Insulated Concrete Forms) has become very popular in the construction industry. ICF have high energy saving characteristics, light weight, high strength, and provide relative simplicity of the facade and interior finishing works. The main types of ICF are the slabs made of foam polystyrene and jointed with integrated rigid elements made of polypropylene or polyethylene by tie pieces made of polyethylene or polypropylene [7].

A solution, that combines cladding and insulation facade materials in one structure, are facade thermal panels which are composed of thermal insulation (polyurethane foam, polystyrene foam (extricable and foaming) and adhered masonry veneer produced by leading manufacturers (Fig.3,e).

There appear heat-insulating materials, oriented towards one of the main qualities of design and construction of bio-positive buildings - sustainability. One of them is flax heatinsulation material. Flax fiber, unlike mineral thermal insulation, can absorb and release moisture without condensation. This makes its heat-insulating properties stable. Moreover 
the use of such heat-insulating material does not require the vapor barrier sheet. The life cycle of slabs from flax fiber guaranteed by manufacturers, is 60 years (Fig.3).
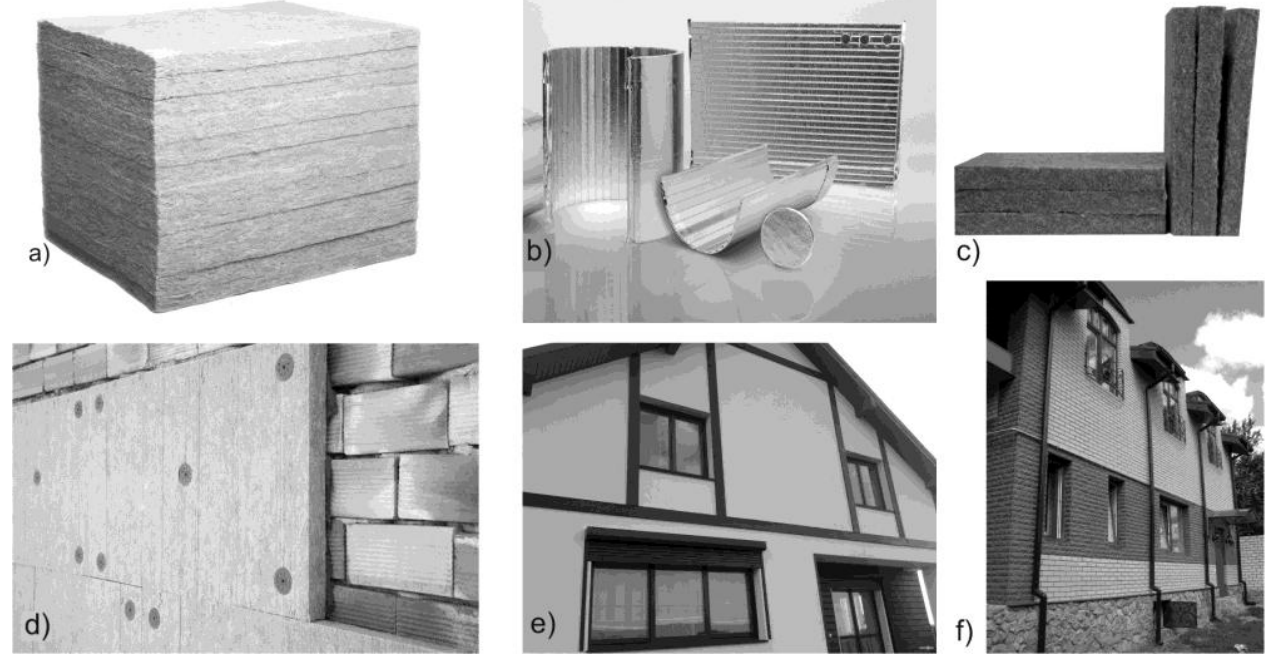

Fig.3. a) mats and slabs from basalt continuous fiber; b) vacuum insulation panels (VIP); c) thermal insulation slabs made of flax fibers; d) thermal insulation slabs; e) liquid thermal insulation based on calibrated ceramic and silicone microspheres with rarefied air;f)facade thermo-panels from thermal insulation(polyurethane foam, polystyrene foam (extrudable and foaming) and adhered masonry veneer.

One of the innovative offers on the market of heat-insulating materials is vacuum insulation. It is noteworthy that physical parameters of this insulation type were obtained in the 60 -ies of the XX century. However, the mass introduction of this material into construction industry started a few decades later. The most important part of the heat transmission process in porous materials is gas stored in pores. The smaller the sizes of pores or hollows in the material structure are and the more complicated the material structure is, the faster the condition of high vacuum and therefore its thermal properties are achieved"[7]. Today, the main material for vacuum panels is polyurethane foam, settled and smoky earth silicon, polystyrene foam and various aero gels. According to Western experts, vacuum insulation panels (VIP) provide 10 times higher thermal efficiency than traditional insulation materials. However, it is necessary to mention that the use of VIP in the construction industry is held back the continuing uncertainty about the problem of longterm thermal insulation which is insured by the vacuum shell (Fig.3,b).

One of the types of vacuum insulation is liquid thermal insulation that has been used for over a decade, but still remains an innovation on the building materials market. It's a kind of paint and varnish material, that forms energy-saving coating after it dries. The material consists of calibrated ceramic and silicone microspheres with rarefied air, which, during the processor the material polymerization create "vacuum". Also one of the advantages is the fact that liquid thermal insulation of walls on the inner side economizes the living space of the building (Fig.3,d) [7].

Awareness of the most advanced innovative thermal insulation materials and technological methods, actively introduced in low-rise housing construction, allows to conclude that with the help of skillful combination of these materials and technologies designers have a vast range of tools to ensure energy efficient and environmentally friendly low-rise building construction even in Northern countries (Canada, Sweden, Finland, Russia). 


\subsection{Energy efficient architectural design}

In countries with temperate climate about one third of all consumed energy is spent on energy supply to buildings, so the energy saving potential in residential sector is very significant. Architectural and engineering solutions of the sustainable design ensure the efficient expenditure of nonrenewable energy resources during construction and operation of suburban houses with high energy consumption indexes during the whole year. Depending on the energy consumption and generation there are several types of buildings:

a) the "passive house" - energy-efficient house, where due to optimal space-planning, architectural and constructive solutions, heat loss is minimized;

b) the "passive solar house" - energy efficient house with increased absorption of solar radiation without using engineering devices for heat storage;

c) the "energy-active solar house" - a building with minimal energy losses, which has a special engineering equipment to intake, distribute and accumulate heat.

Requirements to architectural and design solutions of the "passive" house:

1. Energy rational location of the house on the plot (according to cardinal points and the wind rose) with due account for features of the landscape. The building should be oriented so as not to be placed in the way of prevailing winds. The rational location of wind-proof elements: for protection from cold winds from the Northern or downwind directions in winter [8].

2. Reducing the perimeter of exterior walls of the building - excessive irregularity of spacial arrangement and small size of rooms increase heat loss. Bay windows, glazed portals are the channels of heat leakage [9].

3. Energy rational interlocation of the heated space of the house and unheated summer premises (verandas, sheds, outbuildings) that is a barrier to heat loss of the heated space and when moving from one part to another.

4. Increased insulation (2-3 times greater than required) and sealing of building envelope, elimination of air infiltration through window and door openings, the use of triple glazing, double glazing of "thermal mirror" type, filled triple-pane windows [10]. The buildingalmost always loses energy in the form of heat. There are three main channels of heat loss: through building envelope, through windows and together with the warm ventilated air. It is possible to use increased insulation in any design concepts - brick, monolithic buildings, prefabricated structures, constructions with a variety of nonremovable formwork, buildings made of metal and timber structures [11]. To use thermal insulation properties of the soilrationally, it is necessary to dig the Northern façade deeper into the soil.

The first passive house in Germany was built in 1991 with the support from the Ministry of Economy of the federal state Hesse in Darmstadt, the district of Kranichstein. This building needs such a small amount of heat that it would be really possible not to use a separate heating system: consumption for heating is less than 1 liter of liquid fuel per year for $1 \mathrm{sq} \mathrm{m}$ of heated area [12-16].

The first house designed according to passive house standards in Germany was erected in 1991 in the city of Darmstadt, the district of Kranichstein. In this building heating costs amount to less than 1 liter of liquid fuel per year for $1 \mathrm{sq} \mathrm{m}$.

In 2011 in Moscow Region the first building according to the standards of a passive house was built by German architect Thomas Knecht. The project put into practice all principles of a passive house - increased insulation of building envelope, triple glazing, heat recuperator etc.).The building has passed a unique tightness test: the air is pumped out from the building or additional air is pumped in and then it is measured how the building shell withstands pressure. The building was erected based on the technology of non-removable 
formwork - the supporting structure is a $15-\mathrm{cm}$ reinforced concrete one which is arranged in the formwork made from foam polystyrene which is $10 \mathrm{~cm}$ (outer layer) and $5 \mathrm{~cm}$ (internal) thick. As additional insulation - Neopor insulating material, based on polystyrene of the new generation -was used (Fig.4,a).

A typical passive house project P1 was developed in cooperation with architectural Studios Archix and Pollio especially for the climate of the Russian Federation, Kazakhstan and Ukraine. The design of the building provides all modern solutions by the German Institute of Passive houses that ensure energy efficiency. For example, the heat pump, mechanical ventilation with heat recuperating, the lack of glazing on the Northern side of the house, super warm walls etc. (Fig.4,b).
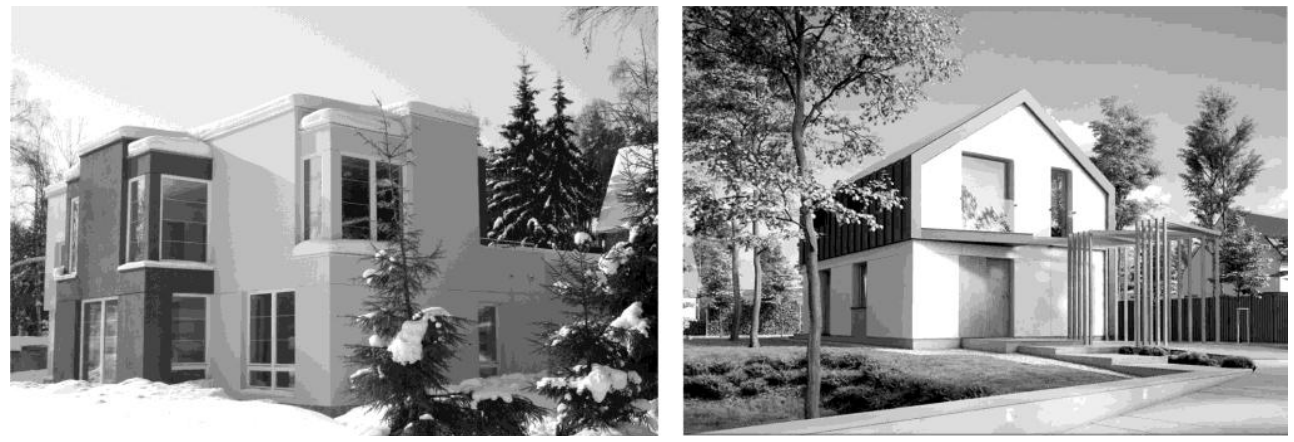

Fig.4. a) the individual house, based on the technology "passive house", Butovo, the Moscow Region, in 2011, the developer company "Mosstroy-31", by architect Thomas Knecht, Germany; b) typical project of a passive house R1, Architectural Studio Archix and Pollio, Russia.

\section{Discussion}

At present, there are several main discussion points in Russia dealing with energy-efficient construction. First of all, it is economic efficiency of these constructions. Russian legislation does not provide any privileges or preferences for initiators who use the methodology of "sustainable design" in building and construction. This paper explains in what way sustainable architectural design of low-rise residential buildings should be performed. The methods described in this paper give an idea not only of innovations in this study area, but also indicate that both evolutionary ways of life and traditions in the individual housing are part of the design methodology and the rationalization of house construction.

\section{Conclusions}

Reference to the regional construction traditions, the standards of a "passive house", energy-efficient design regulations, the concept of a "growing house", the principle of planning transformations are the basis for theoretical modeling of a bio-positive building. They have become part of the methodology of sustainable architectural and town-planning design.

\section{References}

1. S.V. Pugachev, Yu. A. Tabunschikov, A. L. Naumov, Academia. Architecture and Civil Engineering 1, 108-116 (2012). 
2. Z. K. Petrova, Science, education and experimental design. Proceedings of Moscow Institute of Architecture: materials of international scientific-practical conference, 265-271 (2012).

3. [Electronic resource]: Access mode: Internet: -http://muromec43.com/doma/ dom-navyrost.html.

4. O.N. Trapeznikova, Newsletter of the Association of History and Computing 35, 7677 (2008).

5. L. V. Hihluha, R. D. Bagirov, Architecture of the Russian village. Regional aspect (2005).

6. [Electronic resource]: Access mode: Internet:http://www.ruskadom.ru/ houses/ruska80.

7. Innovative construction materials and technologies: their influence on the development of town planning and urban environment. World experience, Russian view. DOKLAD NIU Higher School of Economics, Institute of Innovation Management (2013).

8. Keith Moskow, Sustainable facilities, Green Design, Construction, and Operations (2008).

9. Yu. A. Tabunschikov, Architecture and construction of Moscow 2-3, 14-23 (2003).

10. A. E. Elokhov, Windows, doors, facades 1 (51), 2014.

11. Steven V. Szokolay,Introduction to architectural science. The Basis of Sustainable Design (2008).

12. E.A. Sukhinina, Urban Construction and Architecture 2(10), (2013).

13. V. Murgul, Procedia Engineering, 117, 808-818 (2015)

14. E. Aronova, N. Vatin, V. Murgul, Procedia Engineering, 117, 771-779 (2015)

15. Ž. Jakšić, M. Trivunić, V. Murgul, Procedia Engineering, 165, 891-897 (2016)

16. N. Harmathy, V. Murgul, Procedia Engineering, 165, 1845-1852 (2016) 